\title{
Holistic Education: A Needful System of Education for Learners in Conflict Affected Areas in Nigeria
}

\author{
Muhammed D. Kaigama; Habiba Audu \\ Physics Department C.O.E., P.M.B. 1021, Zing, Taraba State, Nigeria. \\ Department Of Home Economics, C.O.E., P.M.B. 1021, Zing, Taraba State, Nigeria.
}

\begin{abstract}
This paper examines the interconnections between holistic education and education of learners in conflict affected areas in Nigeria. It is not uncommon that the two engaged and integrated at once so that issues in conflict affected areas are addressed in holistic education. The paper posits that education is central to shaping attitudes and social interaction and both are critical to addressing the legacies of conflict. This is based on the feelings that learners in the conflict affected areas are not being given transformative education to align them with the community. The paper argues that holistic education teaches learners how to care about the world, because being care about the world, means being care about our communities. It is believed that kids learn in communion. To learn in communion means to experience connection. To this end, the paper submits that holistic education could be a functional tool in curbing insurgency in Africa continent and Nigeria in particular provided is properly implemented and monitored towards blending and interfacing local wisdom with global knowledge, values and skills required in contemporary Nigeria society.
\end{abstract}

Keywords: Holistic Education, Contemporary Nigeria, Conflict Area, Education of Learners.

\section{Introduction}

Holistic education is a philosophy of education based on the premise that each person finds identity, meaning, and purpose in life through connections to the community, to the natural world, and to humanitarian values such as compassion and peace. Holistic education aims to call forth from people an intrinsic reverence for life and a passionate love of learning.

The term holistic education is often used to refer to the more democratic and humanistic types of alternative education. Robin and Martin (2003) stressed further by stating that at its most general level, what distinguishes holistic education from other forms of education are its goals, its attention to experiential learning, and the significance that it places on relationships and primary human values within the learning environment.

However, it is believed that education systems are inextricably linked to the states and societies they serve. When states fail, or are defeated, or when ethnic, religious, or ideological cleavages erupt into violence, schooling functions erratically (Elias, 2001). The sources of these disruptions do not end at the edge of state territory. States and their national education systems are increasingly subjected to the transnational (global and regional) reach of information, finance, and military networks based beyond their borders. In addition, the explosion of civil conflicts in the latter half of the twentieth century, coupled with the rise of "asymmetrical warfare" and networks of "sub-state actors," has created an unparalleled exodus among populations caught in these crises.

It could be true that education is central to shaping attitudes and social interaction and both are critical to addressing the legacies of conflict. It could also be true that education can be used to entrench segregation and breed hostility. But many researchers and educationists emphasized the fact that education can have "two faces" or alternative uses in complex environments (Barakat\&Urdal, 2009; Bush \& Saltarelli, 2000; Dupuy, 2010; Kirk, 2011; Miller-Grandvaux, 2009). When used positively, education can help promote peace, provide safe environments, and bridge the gap between humanitarian assistance and sustainable development (Barakat, et. al., 2008; Barakat \& Urdal, 2009). However, if not used responsibly and monitored properly, education can be exclusionary, oppressive, a site of corruption, or serve as propaganda for extremism (Miller-Grandvaux, 2009).

Most contemporary thinking now focuses on how to develop critical thinking skills rather than just focusing on a central narrative. There is an imperative to develop an education system which does not just focus on reading, writing and arithmetic but also equips young people to deal with issues of peace and diversity. It is against this back drop, the paper addresses education of learners in conflict affected areas in Nigeria with emphasis on degree of insurgency in northern states and its consequences on educational attainment of these learners with a view to curbing insurgency through holistic education approach. 


\section{Conceptual Framework: Holistic Education}

Holistic education is a philosophy of education based on the premise that each person finds identity, meaning, and purpose in life through connections to the community, to the natural world, and to spiritual values such as compassion and peace (Miller, 1997). It is based on the philosophy of 'holism'. It involves the integration of multiple layers of meaning and experience through direct engagement with the environment. Holistic education is more concerned with drawing forth the latent capacities and sensitivities of the soul than with stuffing passive young minds with pre-digested information. It is an education that prepares young people to live purposefully, creatively, and morally in a complex world (Adeolu, 2011).

To understand the meaning of holistic education, there is need to recognize two principles. Firstly, an education that connects the person to the world must start with the person - not some abstract image of the human being, but with the unique, living, breathing boy or girl, young man or woman (or mature person, for that matter) who is in the teacher's presence. Each person is a dynamic constellation of experiences, feelings, ideas, dreams, fears, and hopes. Secondly, we must respond to the learner with an open, inquisitive mind and a sensitive understanding of the world he or she is growing into (Miller, 2000).

Some advocates of holistic education claim that views central to it are not new but are, in fact, timeless and found in the sense of wholeness in humanity's religious impetus and inspiration from great philosophers, both eastern and western. In fact, the principles and practices of holistic education are already used by a number of institutions that are dissatisfied with traditional education, but they may be unaware of any critical theory about holistic education.

Joseph (2009) identified the core qualities of holistic education as follows;

- There is concern for the interior life, for the feelings, aspirations, ideas and questions that each student brings to the learning process. Education is no longer viewed as the transmission of information; instead it is a journey inward as well as outward into the world.

- Holistic education expresses an ecological consciousness; it recognizes that everything in the world exists in context. This involves a deep respect for the integrity of the biosphere, if not a sense of reverence for nature.

- It is a worldview that embraces diversity, both natural and cultural. It shuns ideology, categorization, and fixed answers, and instead appreciates the flowing interrelatedness of all life.

- It is an education that recognizes the innate potential of every student for intelligent and creative thinking. It is child-honouring education, because it respects the creative impulses at work within the unfolding child as much as, if not more than, the cultural imperatives that conventional schooling seeks to overlay onto the growing personality.

Thus, holistic education is essentially a democratic education, concerned with both individual freedom and social responsibility. It is education for a culture of peace, for sustainability and ecological literacy, and for the development of humanity's inherent morality and spirituality (Cox, 2007).

In describing the general philosophy of holistic education, Martin and Forbes (2004) divide their discussion into two categories: the idea of Ultimacy and Basil Bernstein's notion of Sagacious Competence.

\section{Ultimacy}

1. Religious; as in becoming "enlightened". Spirituality is an important component in holistic education as it emphasizes the connectedness of all living things and stresses the "harmony between the inner life and outer life"

2. Psychological; as in Maslow's "self-actualization". Holistic education believes that each person should strive to be all that they can be in life. There are no deficits in learners, just differences.

3. Undefined; as in a person developing to the ultimate extent a human could reach and, thus, moving towards the highest aspirations of the human spirit.

\section{Sagacious competence}

1. Freedom (in a psychological sense).

2. Good-judgment (self-governance).

3. Meta learning (each student learns in their own way).

4. Social ability (more than just learning social skills).

5. Refining Values (development of character).

6. Self Knowledge (emotional development).

From the foregoing, holistic education could be construed as a pedagogical revolution. It boldly challenges many of the assumptions about teaching and learning, about the school, about the role of the educator, about the need for tight management and standards. Holistic education seeks to liberate students from the authoritarian system of behaviour management that is called education in the modern world. But ultimately, 
holistic education is far more than radical pedagogy: It is an epistemological revolution as well. It demands that we take a hard look at the foundations of the emerging global capitalist culture - the "technological fundamentalism," the worship of money, the assumption that the world is merely made of lifeless matter for man to manipulate and consume.

This new paradigm, this new epistemology is called holism, which challenges addiction to violence, exploitation, and greed. When wholeness is embraced, when Cosmos is recognized as the ultimate source of meaning in life, then we will design not only educational institutions, but social, political, and economic institutions, dedicated to the nourishment and fulfilment of all human beings and the preservation of the ecosphere. To establish this profound connection to the world is to experience an incorruptible reverence for life.

\section{Conflict Affected Areas: Nigerian Perspective}

The word conflict or crisis does not imply peace rather it is anti-peace. As a matter of fact it symbolizes problem in human society. The World Book Encyclopaedia (2004) sees crisis as "a turning point in the course of anything, uncertain time or state of affairs, moment of great danger or difficulty". Conflict, on the other hand, is seen as "to be in opposition to another or each other; disagree. Crises are sudden eruptions of unexpected events caused by previous conflicts.

Kesterner and Ray (2002) see conflict as a social factual situation in which at least two parties (individuals, groups, states) are involved and strive for goals which can only be reached by one party, and or want to employ incompatible means to achieve a certain goal. It thus implies struggle over values or claims to status, power and scarce resources in which the aims of the groups or individuals involved are not only to obtain the desired values but to neutralize, injure or eliminate rivals. The two words: crisis and conflict, as earlier stated are "foreign bodies" in human society or relationship. The two situations are disturbance to peaceful coexistence inhuman society and they cause a dent to harmonious relationship within and without a group (John, 2005).

There is actually nothing wrong with conflict; no society that seeks to develop can absolutely do without it. What is often questioned is how man responds to conflict. A poorly handled conflict could become violent or destructive. It could become a crisis. A crisis is said to exist when a conflict persists for too long and seems to defy easy solution. A typical example is the Niger Delta crisis which has been raging for over three decades with a little chance of abatement until recently when the regime of late President UmaruYar'Adua initiated an amnesty programme.

However, it is obvious that conflict and violence affect the internal workings of schools. Pedagogy, curricula, and textbooks can be used either to promote peace and stability, or to inculcate nationalism and perpetuate ethnic or religious hatred. The problems are dramatized by the large number of children affected by social disorder worldwide. For instance, since early 2012, the insurgency of militant group (Boko Haram) has terrorized the northern states of Nigeria, targeting schools, teachers and students. In response to these attacks, Amnesty International issued a report demanding an end to the violence in the hopes of preserving the right to education in this region.

Another typical example is the socio-religious crisis in Jos that broke up in early hours of March 7, 2010. The crisis was between the native Birom people who are predominantly Christians, and the Hausa, Fulani who are migrants and belong majorly to the Islamic religion. As a matter of fact, religious crises are the most recurring crises in Nigeria today. There was hardly any year of rest from religious crisis in the country since 1977. At times, two or three crises happened within some years. Nigeria therefore can count up to fifty (50) religious crises from 1977 till date (Alabi, 2010).

Presently, religious crisis in Jos is yet to be settled, prominent among religious crises in Nigeria are: crises between Muslims and Christians, Muslims and Muslims, Muslims and Traditional Worshippers and Traditional Worshippers and Christians. The communal clashes in Nigeria are also innumerable. One cannot forget in a haste the 1997 Ife-Modakeke crises, the ArogboIjaw-UgboIlaje crises of 1999 and Aguleri-Umuleri communal crises of 2001-2004 among others.

The effects of individual attacks or threats of attack have long-term impacts on education. If displaced people do access education, how is that recognised on their return to their community, and how can a skilled workforce of teachers be maintained? We see a weakened teaching workforce and further setbacks for education in conflict affected areas. For example, between 2010-2013, many students, teachers or lecturers and hosting community members of tertiary institutions of learning were killed in University of Kano, University of Jos, University of Maiduguri, College of Education Yobe, Gombe State University, etc. This trend of insurgency placed Nigerian educationist in threshold of providing transformative education for the learners in those affected areas. 


\section{Synergy between Holistic Education and Learners in Conflict Affected Areas in Nigeria}

The grave issues in our times-ethnic conflict, violence, terrorism, genocide, war, massive displacement of peoples living in subhuman conditions, poverty, hunger, disease, ignorance, addiction, environmental decay, increase in juvenile crimes, child abuse-not only remain unsolved but have grown in almost uncontrollable proportions, despite the so-called scientific and technological advancement. How can we continue to talk about the quality of education when we cannot even begin to alleviate the human condition? How can we continue to work towards development in a violent, unjust and turbulent world? There can be no development without peace, just as there is no peace without development.

A massive radical change is needed in our egoistic lifestyles, our irresponsible production and consumption patterns, our destructive ways of ravaging our environment. We must work together towards a reeducation of humankind, an attitudinal and behavioural revolution of the mind, heart and will if we want to save humankind from total disaster.

The challenges posed by our rapidly changing world and the major tensions that we face have been addressed in many ways. The new educational paradigm of Lifelong Education (i.e., learning how to learn, based on the four pillars of education: learning to know, learning to do, learning to live together and learning to be) is the master key to meet the challenges of our century (UNESCO, 2006).

Education should be viewed as fundamental for personal and social development, as well as an instrument for peace and tolerance, non-violence and international understanding. Quality of education will then be considered not in fragmented or purely pragmatic and instrumental terms, but in a more holistic manner, the development of all the talents of the individual; the formation of the whole person, the full flowering of all the human powers and faculties (physical, intellectual, affective, aesthetic, ethical, and spiritual), and the transformation of society.

No doubt the phenomenal advances in science and technology, the information and communication revolution have made dramatic breakthroughs in our lives; but they have not prevented the breakdowns in the social moral order, the upsurge in crime and violence, the erosion of human, ethical, cultural and spiritual values (Joseph, 2009).This was supported by Cox (2007) when he calls for values dimension in education and society. Stressing that science with a conscience and technology with a human heart at the service of humanity is needed for millennium education. In other words, there is need for holistic and integrated education of the human person in a learning society.

In the same vein, UNESCO's Medium Term Strategy (2002-2007) Draft 31 C/4 Contributing to peace and human development in an era of globalization has defined as its first domain of action: Culture of peace through education, and pointed out poverty and conflict as the prime causes which put human security at risk, and endangers human dignity and social justice.

All of the leading holistic thinkers identify the crisis of our time as an epistemological crisis. We are not arguing against technology as such, or against capitalism in itself. We are saying that underneath our political, social, and economic arrangements, the way modern culture defines and understands reality itself is faulty, and this flawed way of knowing gives rise to distorted, we might even say cancerous, forms of technology and economic organization. Educational philosopher Douglas Sloan (1983) refers to this as a "technicist" way of knowing. David Orr (1994), one of the leading theorists of environmental education, attacks what he calls "technological fundamentalism." Other holistic writers commonly identify "reductionist" or "mechanistic" ways of thinking and knowing as the primary problem of our civilization. All these terms point to the utilitarian, manipulative, objectivist, and overly rational ways of treating the earth and the life that inhabits in it.

The purpose of holistic education either in Nigeria or any other place is to prepare students to meet the challenges of living as well as academics. Put differently, holistic education aims to call forth from young people an intrinsic reverence for life and a passionate love of learning. This is done, not through an academic 'curriculum' that condenses the world into instructional packages, but through direct engagement with the environment.

Holistic education does not simply instruct young people about what is true and what is false, but enables the learner to inquire: what does this mean? How is this experience, or this fact, or this advertising message related to other things I know? If I act on my understanding, how will that affect other people, or the habitat of other living beings? This encourages young people to care about the world they live in. Other people matter, the natural world matters. Cultural heritage, social responsibility, and ethics matter.

In the case conflict affected areas in Nigeria, holistic education aims to call forth from people an intrinsic reverence for life and a passionate love of learning. In this wise, to educate young people in Nigeria means helping them bring forth their creativity, their compassion, their curiosity, their moral and aesthetic sensitivity, their critical intellectual skills, their ability to participate in a robust democracy. In other words, 
holistic education aims at the wholeness of the learner in order to promote common identity and goal of Nigerian society.

\section{Recommendations}

Having gone through the state of insurgency in Nigeria, it is obvious that conflict and violence affect the internal workings of schools. While education could either be used to promote peace and stability, or to inculcate nationalism and perpetuate ethnic or religious hatred. This paper recommends a holistic education approach to the teaching and learning of learners in conflict affected areas in Nigeria. Because, it is strongly believed that if properly implemented and monitored, holistic education blends and interfaces local wisdom with global knowledge, values and skills, which will develop the student to become a citizen of his/her country as well as a citizen of the global village.

\section{Conclusion}

From the above, it could be surmised that in holistic education, the teacher is seen less as person of authority who leads and controls but rather is seen as a friend, a mentor, a facilitator, or an experienced travelling companion. Schools are seen as places where students and adults work towards a mutual goal. Open and honest communication is maintained and differences between people are respected and appreciated. Cooperation is the norm, rather than competition. Thus, many schools incorporating holistic beliefs do not give grades or rewards. The reward of helping one another and growing together is emphasized rather than being placed above one another.

A holistic and integrated education towards a complete human person may seem to be an unrealistic and an impossible task, since the things that count cannot be counted, and what matters most may be invisible to the eye. It is only when we have the power to value that we will be able to distinguish the essential from the non-essential, and to realize that the dignity of the human person and the excellence of the human spirit are the ultimate criteria of quality.

At this point, it may be said that standards of quality in this age of globalism and IT can be met only through a holistic approach to education which veers away from rigid compartmentalization of content to a more multidisciplinary, interdisciplinary view of reality; authoritarian teacher-centred teaching strategies to more democratic, participatory, interactive learning methods; content-focused teaching to a holistic cognitiveaffective-behavioural teaching learning cycle; prepared and fixed modules to flexible and adaptable guides to teaching and learning; values-free to values-integrated subject matter with emphasis on the valuing process; mere information to formation and transformation; academic excellence alone to moral excellence, character building and personality development.

Finally, as mentioned above, conflict affected community is an integral aspect in holistic education. As relationships and learning about relationships are keys to understanding ourselves, so the aspect of community is vital in this learning process. Thus, in holistic education the classroom is often seen as a community, which is within the larger community of the school, which is within the larger community of the village, town, or city, and which is, by extension, within the larger community of humanity.

\section{References}

[1]. Alabi, A.O. (2010). The Nigerian nation and management of conflicts and crises. Lead paper presented at the Annual National Conference of the School of Arts and Social Sciences, Federal College of Education (SP) Oyo, 9th June 2010.

[2]. Adeolu, T. E. (2011). Teacher education in Nigeria: Problems and issues. In B.O. Ukeje, L. O. Ocho \& E. O. Fagbamiye (Eds) Issues and concern in educational administration: The Nigerian case in international perspective. Lagos: Macmillan

[3]. Barakat, L. et al (2008). Can education interrupt fragility: Toward the resilient citizen and adaptable state. In K. Mundy, \& S. Dryden-Peterson (Eds.), Educating children in conflict zones: Research, policy, and practice for systemic change (pp. 33-48). New York: Teacher's College Press.

[4]. Barakat, B., and Urdal, H. (2009). Breaking the waves? Does education mediate the relationship between youth bulges and political violence? Washington, D.C.: World Bank. Retrieved from http://econ.worldbank.org/external/default/main?pagePK=64165259\&theSitePK=477916\&piPK=6416542 $1 \&$ menuPK=64166093\&entityID $=000158349 \_20091105103139$

[5]. Bush, K. D., and Saltarelli, D. (2000). The two faces of education in ethnic conflict. Florence: UNICEF. Retrieved from http://www.unicef-irc.org/publications/pdf/insight4.pdf

[6]. Cox, M. (2007). Access to quality education for children and youth with disabilities in conflict, crisis and stable countries. Background Report. (Unpublished Report). Washington, D.C.: USAID.

[7]. Orr, David. (1994). Earth in Mind: On Education, Environment, and the Human Prospect. Washington, D.C.: Island Press. 
[8]. Dupuy, K. (2010). Education that builds peace or fuels armed conflict. In H. B.Holmarsdottir, \& M. O. (eds.), Nordic voices: Teaching and researching comparative and international education in the. Rotterdam: Sense Publishers.

[9]. Elias, M. (2001). Prepare children for the tests of life, not a life of tests. Education Week, 40.

[10]. John, B. (2005). Holistic Special Education: Camphill Principles and Practice. Edinburgh: Floris Books.

[11]. Joseph, R. (2009). Promoting quality education in refugee contexts: Supporting teacher development in northern Nigeria. New York, N.Y.: International Rescue Committee. Retrieved fromhttp://www.healingclassrooms.org/downloads/Promoting_Quality_Education_\%20Refugee_Contexts. pdf

[12]. Kesterner, B.P. and L. Ray, (2002). The Conflict Resolution Training Programme Leader's Manual. Jossey-Bass, USA.

[13]. Kirk, J. (2011). Addressing gender disparities in education in contexts of crisis, post crisis, and state fragility. In K. Mundy, \& Dryden-Peterson (Eds.), Educating children in conflict zones: Research, policy, and practice for system change (pp. 67-82). New York: Teacher's College Press.

[14]. Martin, A. R. and Forbes, S. H. (2004). What Holistic Education Claims About Itself: An Analysis of Holistic Schools' Literature. Paper presented at the American Education Research Association Annual Conference (San Diego, California, California, April 2004). 26 pages.

[15]. Miller-Grandvaux, L. (2009). Education and Fragility: A New Framework. Journal of Education for $\begin{array}{llll}\text { International } & \text { Development, } & \text { R(1). } & \text { Retrieved }\end{array}$ http://www.gsdrc.org/go/display\&type=Document\&id=3486

[16]. Miller, R. (2000). Creating Learning Communities: Models, Resources, and New Ways of Thinking About Teaching and Learning. Brandon, VT: Holistic Education Press.

[17]. Sloan, Douglas. 1983. Insight-imagination: The Emancipation of Thought and the Modern World. Westport, CT: Greenwood Press.

[18]. United Nations Educational, Scientific and Cultural Organization (UNESCO, 2006). Education for All global monitoring report 2006: Reaching the marginalized. Paris: UNESCO.

[19]. World Book Inc., 2004. The World Book Encyclopaedia. Vol. 14, World Book Inc., Chicagohttp://www.holistic-education.net/articles/research04. 